\title{
Peran Pondok Pesantren dalam Membentuk Karakter Bangsa Santri di Era Disrupsi
}

\author{
Pasmah Chandra \\ Institut Agama Islam Negeri (IAIN) Bengkulu, \\ pasmah@iainbengkulu.ac.id
}

\begin{abstract}
Character education has become a phenomenon and an interesting discussion since the last few years. To make matters worse, many educational figures have discussed and conducted research on character education, by connecting character education with the role of educators or educational institutions themselves. Likewise, seeing the role of Islamic boarding schools in character education in the era of disruption. So far the existing studies have not explicitly discussed the process of shaping the character of the nation by Islamic boarding schools. This study aims to complement the previous studies with the aim; first, to determine the role of character education in the students of the Manna AlQuraniyah Islamic Boarding School. Second, knowing the factors inhibiting and supporting the implementation of character education in the Al-Quraniyah Manna Islamic boarding school students. This type of research is field research with a qualitative approach. The results of the research are as follows: first, the role of the Islamic boarding school in shaping the character of the students can be seen in the implementation of character education at the Al-Quraniyah Manna Islamic boarding school which is carried out through the material taught in the Islamic boarding school then through these materials the students are able to practice it correctly. The implementation of character education is also carried out through the example of kyai, dormitory caregivers, teachers who interact with them, especially those in the boarding school environment. The biggest source of character education implementation comes from the Islamic boarding school program/activity. For example, local content and extracurricular activities. Second, the inhibiting and supporting factors for the implementation of character education consist of internal factors (lack of infrastructure, lack of teaching staff) and external factors (the influence of technological developments).
\end{abstract}

Keywords: Role, National Character Education, Islamic Boarding School

Abstrak: Pendidikan karakter menjadi fenomena dan pembahasan menarik sejak beberapa tahun terakhir ini. Parah ahli, tokoh pendidikan telah banyak yang membahas dan melakukan riset mengenai pendidikan karakter, dengan cara menghubungkan pendidikan karakter dengan peranan para pendidik atau lembaga pendidikan itu sendiri. Begitu juga dengan melihat peranan dari Pondok Pesantren dalam pendidikan karakter di era disrupsi. Sejauh ini studi yang ada belum membahas secara eksplisit mengenai proses pembentukan karakter bangsa oleh Pondok Pesantren. Penelitian ini bertujuan untuk melengkapi dari studi terdahulu dengan tujuan; pertama, untuk mengetahui peran pendidikan karakter pada santri Pondok Pesantren Al-Quraniyah Manna. Kedua, mengetahui, faktor-faktor penghambat dan pendukung implementasi pendidikan karakter pada santri pondok pesantren Al-Quraniyah Manna. Jenis penelitian ini ialah penelitian lapangan dengan

Belajea: Jurnal Pendidikan Islam Vol. 5, No 2, 2020; 243-262

p-ISSN 2548-3390; e-ISSN 2548-3404, DOI:10.29240/belajea.v5i2.1497

http://journal.iaincurup.ac.id/indek.php/belajea 
pendekatan kualitatif. Hasil penelitian sebagai berikut: pertama, peran pondok pesantren dalam membentuk karakter santri tampak pada impelementasi pendidikan karakter pada pondok pesantren al-Quraniyah Manna dilakukan melalui materi yang diajarkan di pondok pesantren kemudian melalui materi tersebut santri mampu mengamalkannya dengan benar. Impelementasi pendidikan karakter juga dilakukan melalui keteladanan para kyai, pengasuh asrama, guru yang berinteraksi dengan mereka khususnya yang ada di lingkungan pondok pesantren. Sumber impelementasi pendidikan karakter terbesar ialah berasal dari program/kegiatan Pondok Pesantren. Misal kegiatan muatan lokal dan ekstrakurikuler. Kedua, faktor penghambat dan pendukung impelementasi pendidikan karakter tersebut terdiri dari faktor internal (kurangnya sarana prasarana, kurangnya tenaga pengajar) dan faktor eksternal (pengaruh perkembangan teknologi).

Kata Kunci: Peran, Pendidikan Karakter Bangsa, Pondok Pesantren

\section{Pendahuluan}

Karakter merupakan nilai-nilai perilaku manusia yang berhubungan dengan Tuhan Yang Maha Esa, diri sendiri, sesama manusia, lingkungan, dan kebangsaan yang terwujud dalam pikiran, sikap, perasaan, perkataan, dan perbuatan berdasarkan norma-norma agama, hukum, tata krama, budaya, dan adat istiadat. ${ }^{1}$ Pendidikan karakter dapat diterapkan dalam pembelajaran pada setiap mata pelajaran. ${ }^{2}$ Materi pembelajaran yang berkaitan dengan norma atau nilai-nilai pada setiap mata pelajaran perlu dikembangkan, dieksplisitkan, dikaitkan dengan konteks kehidupan sehari-hari. ${ }^{3}$ Model pendidikan karakter anak yang berupaya mencakup total moral kehidupan sekolah. Model tersebut terdiri dari 12 strategi, 9 untuk kelas dan 3 untuk seluruh sekolah. Sembilan strategi kelas meliputi: komunitas kelas yang peduli, disiplin moral, lingkungan kelas yang demokratis, pengajaran nilai-nilai melalui kurikulum, pembelajaran kooperatif, hati nurani kerajinan, refleksi etika, pengajaran resolusi konflik, dan guru sebagai pengasuh, model, dan mentor. Ketiga strategi sekolah adalah peduli di luar kelas, menciptakan budaya moral yang positif di sekolah, dan sekolah, orang tua, dan masyarakat sebagai mitra. ${ }^{4}$ Dengan demikian, pembelajaran nilai-

1 Abdul Jalil, "Karakter Pendidikan Untuk Membentuk Pendidikan Karakter," Nadwa, 2016..

2 Yadi Ruyadi, "Model Pendidikan Karakter Berbasis Kearifan Budaya Lokal (Penelitian Terhadap Masyarakat Adat Kampung Benda Kerep Cirebon Provinsi Jawa Barat Untuk Pengembangan Pendidikan Karakter Di Sekolah)," Proceedings of The 4th International Conference on Teacher Education; Join Conference UPI \& UPSI, 2010.

${ }^{3}$ Oci Melisa Depiyanti, "Model Pendidikan Karakter Di Islamic Full Day School (Studi Deskriptif Pada SD Cendekia Leadership School, Bandung)," TARBAWY: Indonesian Journal of Islamic Education, 2014.

4 Thomas Lickona, "Educating for Character: A Comprehensive Approach," in The Construction of Children's Character., 1997. 
nilai karakter tidak hanya pada tataran kognitif, tetapi menyentuh pada internalisasi, dan pengamalan nyata dalam kehidupan peserta didik sehari-hari di masyarakat. $^{5}$

Pendidikan karakter di pondok pesantren sangat terkait dengan manajemen atau pengelolaan pondok pesantren. Pengelolaan yang dimaksud adalah bagaimana pendidikan karakter direncanakan, dilaksanakan, dan dikendalikan dalam kegiatan-kegiatan pendidikan di pondok pesantren secara memadai. ${ }^{6}$ Pengelolaan tersebut antara lain meliputi, nilai-nilai yang perlu ditanamkan, muatan kurikulum, pembelajaran, penilaian, pendidik dan tenaga kependidikan, dan komponen terkait lainnya. Dengan demikian, manajemen pondok pesantren merupakan salah satu media yang efektif dalam pendidikan karakter di pondok pesantren.

Pembentukan karakter harus dilakukan secara sistematis dan berkesinambungan yang melibatkan aspek "knowledge, feeling, loving, dan acting". Pada dasarnya, anak yang kualitas karakternya rendah adalah anak yang tingkat perkembangan emosi-sosialnya rendah, sehingga anak berisiko besar mengalami kesulitan dalam belajar, berinteraksi sosial, dan tidak mampu mengontrol diri. ${ }^{8}$ Berbagai masalah bangsa Indonesia diberbagai bidang selama ini tidak lepas dari karakter dan nilai-nilai masyarakat. Kalau saat ini banyak kritik yang terkait dengan karakter bangsa, maka pondok pesantren sebagai salah satu lembaga pendidikan, ikut bertanggung jawab untuk mengatasi permasalahan tersebut. "Banyak orang berpandangan bahwa kondisi demikian diduga bermula dari apa yang dihasilkan oleh dunia pendidikan. Pendidikanlah yang sesungguhnya paling besar memberikan kontribusi terhadap situasi ini”. Anak-anak yang telah melewati sistem pendidikan selama ini, mulai dari pendidikan pondok pesantren kurang memilik kemampuan mengelola konflik dan kekacauan, sehingga anakanak dan remaja selalu menjadi korban konflik dari kekacauan tersebut. ${ }^{9}$

Untuk mengatasi penyakit masyarakat dan berbagai persoalan yang terjadi belakangan ini serta meningkatnya kualitas pendidikan seperti yang telah disebutkan di atas, ternyata pendidikan karakter diharapkan mampu menjadi

${ }^{5}$ Zainun Wafiqatun Niam, "Membina Karakter Anak Melalui Program Full Day School Berbasis Nilai-Nilai Kepesantrenan (Studi Kasus Di Madrasah Ibtidaiyah Nurul Ummah Kotagede Yogyakarta)," BELAJEA: Jurnal Pendidikan Islam, 2019.

6 "Potret Pendidikan Karakter Di Pondok Pesantren Salafiah," Jurnal Pendidikan Karakter, 2013.

7 Ahmad Janan Asifudin, "Manajemen Pendidikan Untuk Pondok Pesantren," MANAGERLA: Jurnal Manajemen Pendidikan Islam, 2017.

8 A Muchaddam Fahham, "Character Education in Islamic Boarding School," Aspirasi, 2013.

9 HAERANI NUR, "Building Children's Character through Traditional Games," Junal Pendidikan Karakter, 2013. 
modal dasar untuk mengatasi masalah Pendidikan karakter di Bengkulu Selatan sebenarnya sudah diterapkan. Berbagai upaya ditempuh oleh pihak pondok pesantren guna menerapkan pendidikan karakter. Salah satunya dengan menerapkan sistem pendidikan terpadu selama 24 jam. Di Indonesia sendiri munculnya pondok pesantren berasrama (Boarding School) sejak pertengahan tahun $1990 .{ }^{10} \mathrm{Hal}$ ini dilatarbelakangi oleh kondisi pendidikan Indonesia yang selama ini berlangsung dipandang belum memenuhi harapan yang ideal. Pondok pesantren yang pola pendidikannya lebih komprehensif holistik lebih memungkinkan untuk menciptakan lingkungan pendidikan yang ideal untuk melahirkan orang-orang yang akan dapat membawa gerbong dan motor pergerakan kehidupan sosial, politik, ekonomi, dan agama. ${ }^{11}$

Pendidikan di pondok pondok pesantren ini diharapkan efektif untuk mendidik kecerdasan, ketrampilan, pembangunan karakter dan penanaman nilainilai moral peserta didik, sehingga anak didik lebih memiliki kepribadian yang utuh dan khas. ${ }^{12}$ Dalam kegiatan kurikuler, kokurikuler, ekstrakurikuler, baik di pondok pesantren, asrama dan lingkungan masyarakat yang dipantau oleh guruguru selama 24 jam. Kesesuaian sistemnya terletak pada semua aktivitas santri yang diprogramkan, diatur dan dijadwalkan dengan jelas. Sementara aturan kelembagaannya sarat dengan muatan nilai-nilai moral. Kelebihan-kelebihan lain dari sistem ini adalah: sistem pondok pesantren lebih menekankan pendidikan kemandirian. Berusaha menghindari dikotomi keilmuan (ilmu agama dan ilmu umum).

Salah satu contoh pondok pesantren yang sudah melaksanakan peranannya dalam menanamkan pendidikan karakter bangsa di era disrupsi dengan cara menerapkan sistem pembelajaran selama 24 jam ialah pondok pesantren al-Quraniyah Manna. Dengan menggunakan program yang terpadu diharapkan dapat menerapkan pendidikan karakter secara lebih efektif. Pendidikan karakter di pondok pesantren ini bertujuan untuk meningkatkan mutu penyelenggaraan dan hasil pendidikan di pondok pesantren yang mengarah pada pencapaian pembentukan karakter dan akhlak mulia peserta didik secara utuh, terpadu, dan seimbang, sesuai standar kompetensi lulusan. Santri pondok pesantren al-Quraniyah Manna secara psikologis memasuki masa remaja, yaitu masa transisi antara seorang anak-anak dan masa remaja.

Sejauh ini studi tentang pesantren cukup banyak, namun cenderung menganalisis pada beberapa aspek, diantaranya; pertama, studi tentang

${ }^{10}$ Herman, “Sejarah Pesantren Di Indonesia," Jurnal Al-Ta'dib, 2013.

11 Muhammad Idris Usman, "Pesantren Sebagai Lembaga Pendidikan Islam (Sejarah Lahir, Sistem Pendidikan, Dan Perkembangannya Masa Kini)," Jurnal Al-Hikmah, 2013.

12 Abdullah Zawawi, "Peranan Pondok Pesantren Dalam Menyiapkan Generasi Muda Di Era Globalisasi,” Ummul Quro, 2013. 
pendidikan karakter pada pesantren salaf. Studi ini menggambarkan bagaimana pesantren salaf dengan mempertahankan ciri khas tradisional dalam menanamkan karakter pada santri. ${ }^{13}$. Kedua studi yang membahas mengenai model pendidikan tolernasi pada pesantren. ${ }^{14}$ Ketiga, Penelitian mengenai pesantren sebagai lembaga pendidikan pembentuk karakter. ${ }^{15}$ Ada juag studi yang membahas mengenai analisis sistem pendidikan di Pesantren. ${ }^{16}$ Kelima, penelitian yang membahas mengenai pengalaman pendidikan di pesantren. ${ }^{17}$ Dari beberapa studi yang berkaitan tentang Pondok Pesantren di atas, belum ada studi yang membahas secara eksplisit mengenai peran Pondok Pesantren dalam membentuk karakter bangsa di era disrupsi. Terutama nilai karakter religius, toleransi, jujur, disiplin, mandiri yang semuanya diajarkan secara komprehensif di Pondok Pesantren.

Tujuan penelitian ini ialah untuk melengkapi penelitian terdahulu yang suda ada terkait pondok pesantren dan pendidikan karakter. Penelitian inti mencoba menjelaskan mengenai peranan pondok pesantren dalam mebentuk karakter bangsa dengan menjelaskan pola-pola yang ditanamkan khusunya di era disrupsi saat ini. Penelitian ini mengungkap bahwa pelaksankaan pendidikan karakter bangsa yang terbaik ialah dilakukan di Pondok Pesantren.

Jenis penelitian ini adalah penelitian lapaangan (field research). Penentuan subjek penelitian merupakan cara untuk menentukan sumber dimana penulis mendapatkan data. Dalam penelitian ini penulis menggunakan purposive sampling yaitu orang-orang terpilih yang akan dikenai pertanyaan dan pernyataanya menurut ciri-ciri spesifik yang dimiliki sampel itu. Sampel tersebut dikendalikan oleh tujuan penelitian. Hal ini dilakukan karena peneliti beranggapan bahwa sampel yang dipilih akan mewakili pola kehidupan yang ada, karena kehidupan di pondok pesantren merupakan kehidupan yang seragam dan di bawah aturanaturan yang ada. Sedangkan menurut Suharsimi Arikunto bahwa subjek penelitian berarti subjek dimana data diperoleh baik berupa orang, respon, benda, gerak dan proses sesuatu.

${ }^{13}$ M. Syaifuddien Zuhriy, "Budaya Pesantren Dan Pendidikan Karakter Pada Pondok Pesantren Salaf,” Walisongo: Jurnal Penelitian Sosial Keagamaan, 2011.

14 Ali Maksum, "Model Pendidikan Toleransi Di Pesantren Modern Dan Salaf," Jurnal Pendidikan Agama Islam (Journal of Islamic Education Studies), 2016.

15 Imam Syafe'i, "Pondok Pesantren: Lembaga Pendidikan Pembentukan Karakter," AlTadækiyyah: Jurnal Pendidikan Islam, 2017.

16 Supriadin Supriadin, "Politik Pendidikan Islam Di Indonesia: Analisis Sistem Pendidikan Pesantren Dan Madrasah," EL-HIKMAH: Jurnal Kajian Dan Penelitian Pendidikan Islam, 2014..

${ }^{17}$ Eka Srimulyani, “ Muslim Women and Education in Indonesia: The Pondok Pesantren Experience ," Asia Pacific Journal of Education, 2007.. 
Berdasarkan uraian di atas, maka yang menjadi subjek dalam penelitian ini adalah; pertama, Pimpinan Pondok pesantren al-quraniyah Manna 1 orang. Kedua, Ustad/ustadza Pondok pesantren al-Quraniyah Manna 7 orang. Ketiga, Pembina Srama Putra Dan Putri Pondok pesantren al-Quraniyah Manna 6 orang. Keempat, Santri Pondok pesantren al-Quraniyah Manna 25 orang. Kelima, Pembina kegiatan ekstrakurikuler di Pondok pesantren 2 orang

Untuk mendapatkan informasi terkait penelitian yang dilakukan, maka alat pengumpulan data yang digunakan berupa observasi, wawancara, dokumentasi dan catatan lapangan. Dalam melakukan observasi peneliti diabntu oleh observer. Observer bertugas untuk mengamati kegiatan santri selama di Pondok Pesantren Al-Quraniyah. Untuk memperkuat data, peneliti melakukan wawancara dengan respon terkait proses pembentukan karakter bangsa pada santri. Wawancara ini dilaksanakan secaar mendalam dengan tujuan dapat memperoleh informasi yang valid dan akurat. Selanjutnya, data tersebut akan di analisis dengan melakukan reduksi data, display data, dan selanjutnya menarik kesimpulan dari penelitian yang dilakukan.

\section{Hasil dan Pembahasan}

\section{Sistem Pendidikan di Pondok Pesantren Al-Quraniyah Manna}

Pondok pesantren Al-Quraniyah merupakan salah satu jenis pendidikan Islam yang bersifat modern mendalami ilmu agama Islam. Pondok pesantren ini merupakan suatu komunitas tersendiri, dimana kyai, ustad, santri dan pengurus hidup bersama yang berlandaskan nilai agama Islam lengakap dengan norma tersendiri, yang secara ekslusif berbeda dengan pendidikan umum. Pondok Pondok pesantren merupakan suatu keluarga besar di bawah asuhan seorang kyai, dan dibantu oleh ustad/guru, dan tenaga administrasi. ${ }^{18}$

Sistem pendidikan di pondok pesantren ini menggunakan pendekatan holistik, artinya para pengasuh pondok pesantren memandang bahwa kegiatan belajar-mengajar merupakan kesatu paduan atau lebur dalam totalis kegiatan kehidupan sehari-hari. ${ }^{19}$ Bagi santri belajar di pondok pesantren tidak mengenal perhitungan waktu, kapan harus mulai dan harus selelesai, dan target apa yang harus dicapai. Bagi dunia pondok pesantren hanya ilmu fardu ain yang dipandang sakral. Dalam pandangan mereka semua kegiatan yang terjadi dalam kehidupan berawal dari Allah Swt, dan berproses menurut hukum, dan berakhir kembali pada-Nya. Setiap peristiwa yang terjadi merupakan bagian dari

${ }^{18}$ Zuhriy, "Budaya Pesantren Dan Pendidikan Karakter Pada Pondok Pesantren Salaf."

${ }_{19}$ Binti Maunah, "Implementasi Pendidikan Karakter Dalam Pembentukan Kepribadian Holistik SISWA,” Jurnal Pendidikan Karakter, 2016/. 
keseluruhan dan selalu berhubungan satu sama lain dan pada akhirnya pasti bertemu pada kebenaran ajaran Allah Swt.

Berdasarkan wawancara peneliti dengan pimpinan pondok pesantren Al-Quraniyah Manna ${ }^{20}$, ia meyakini bahwa apa saja yang dipelajari oleh santri di Pondok pesantren adalah baik dan pada suatu saat akan mendatangkan manfaat bagi yang bersangkutan. Misalnya, seorang santri dengan keterampilan melalui otodidak (seperti: kaligrafi, ternak sapi, berkebun, belajar pencak silat, dll), pada saat ini belum bermanfaat tetapi dalam beberapa tahun kemudian akan memberikan kegunaan.

1. Metode pengajaran

Metode pengajaran pada pondok pesantren Al-Quraniyah diberikan dalam bentuk, sorogan, bandong, halaqah dan hafalan. Sorogan artinya: belajar secara individual dimana seorang santri berhadapan dengan seorang guru, terjadi interaksi saling mengenal antara keduanya. Bandongan artinya belajar secara kelompok yang diikuti seluruh santri, dan biasanya Kiyai menggunakan bahasa daerah setempat dan langsung menerjemahkan kalimat demi kalimat dari kitab yang dipelajarinya. Halaqah artinya diskusi untuk memahami isi kitab, bukan untuk mempertanyakan kemungkinan benar salahnya apa yang diajarkan oleh kitab, tetapi untuk memahami apa maksud yang diajarkan kitab. Santri yakin bahwa Kyai tidak akan mengajarkan hal-hal yang salah dan mereka yakin bahwa isi kitab yang dipelajari adalah benar.

Dalam kegiatan pembelajaran para santri seminggu sekali pada saat shalat isya dan subuh, mengadakan belajar pidato (muhadharoh) atau belajar memberikan ceramah keagamaan. Isi ceramah keagamaan dipilih para santri, tetapi kebanyakan berkisar pada sejarah nabi Muhammad Saw, kepahlawanan, kejujuran para sahabat dan tema aktual lainnya. Para santri juga belajar memberikan kata sambutan dalam berbagai hal, misalnya pesta, sunatan dan kata sambutan lainnya yang dianggap perlu untuk disampaikan. Para santri dalam satu kelompok disebut kafilah, diketuai oleh seseorang dengan jumlah sekitar 30 orang. Semua santri wajib berpidato atau memberikan kata sambutan dalam berbagai hal. Metode pembelajaran yang unik, setiap 3 bulan dilakukan pertandingan antar kafilah. Setiap anggota kafilah dipilih secara demokrasi untuk bertanding dengan anggota kafilah lainnya. Demikian dilakukan untuk setiap jenis yang dilombakan. Bila anggota kafilah kalah, maka teman-temannya menerima dan belajar lebih baik lagi.

Dedi Irama, mengatakan bahwa, dalam satu kelompok kafilah terdiri dari berbagai kelas, dari kelas I s/d kelas VI. Dalam latihan pada malam hari, setiap anggota memberikan pidato dan ceramah keagamaan yang berdurasi

${ }^{20}$ Meki P, Pimpinan Pondok Pesantren, Wawancara, Tanggal 10 Desember 2019 
lebih kurang 10 menit dan selesai sampai jam 21.30 malam. Apabila ada anggota kelompok yang tidak siap tampil, padahal sudah dijadwal maka mereka dihukum, yaitu berdiri dengan memegang telinga sampai kegiatan tersebut selesai. Hal yang unik dari kegiatan ini, semuanya berjalan dengan lancar tanpa ada ustad dan ustazah yang mengawasinya. Kegiatan ini menanamkan kejujuran sejak usia dini, dengan tujuann supaya santri mandiri dan berusaha dengan sekuat tenaga untuk menyiapkan materi yang akan disampaikan. ${ }^{21}$

Bagi santri proses tersebut adalah ibadah kepada Allah SWT. Diperoleh atau tidaknya ilmu sebagai hasil belajar sangat tergantung pada ridah Allah SWT. Melalui usaha dengan segenap kesucian jiwa melalui sholat, puasa dan kegiatan lainnnya, para santri terus belajar. Cara belajar seperti ini tidak memerlukan biaya yang mahal, seperti penyediaan meja belajar, projektor, infokus, laptop dan lain-lain. Para santri biasanya duduk di ambal yang telah disediakan dalam kegiatan pembelajaran.

Untuk menumbuhkan kemampuan berpikir rasional para santri, pihak Pondok pesantren Al-Quraniyah memberikan pelajaran umum dan keterampilan khusus di pondok pesantren seperti: bertani, berternak, menulis kaligrafi dan pekerjaan lainnya yang akrab dengan kehidupan sehari-hari. Kegiatan ini dilakukan saat libur dengan tujuan untuk menyeimbangkan antara ukhrawi dengan duniawi.

2. Pembentukan karakter santri

Ada beberapa prinsip sistem pendidikan pada Pondok pesantren AlQuraniyah dalam membentuk karakter santri, diantaranya sebagai berikut: ${ }^{22}$

a. Theocentric, Pada Pondok pesantren Al-Quraniyah sistem pendidikan didasarkan pada filsafat theocentric. ${ }^{23}$ Setiap santri beraktivitas dipandang sebagai ibadah kepada Allah Swt. Semua aktivitas pendidikan merupakan bagian integral dari totalias kehidupan keagamaan, sehingga kegaitan belajar tidak memperhitungkan waktu. ${ }^{24}$ Dalam prakteknya para santri cenderung mengutamakan sikap dan prilaku yang beroreintasi kepada kehidupan ukhrawi. Semua perbuatan dilaksanakan berdasarkan hukum agama demi kepentingan hidup ukhrawi.

b. Sukarela dalam mengabdi; Para pengasuh Pondok pesantren memandang semua kegiatan pendidikan adalah ibadah kepada Allah Swt, sehingga penyelenggaraan pondok pesantren dilaksanakan secara sukarela dan

${ }^{21}$ Dedi Irama, Pengasuh Asrama Putra, Wawancara, Tanggal 20 Desember 2019

${ }^{22}$ Juliansyah, Pengasuh Pondok Pesantren, Wawancara, Tanggal 7 Januari 2020

${ }^{23}$ Janan Asifudin, "Manajemen Pendidikan Untuk Pondok Pesantren."

24 Srimulyani, " Muslim Women and Education in Indonesia: The Pondok Pesantren Experience." 
mengabdi kepada sesama dalam rangka mengabdi kepada Allah SWT. ${ }^{25}$ Mengingat biaya pendidikan di Pondok pesantren Al-Quraniyah sangatlah minim, maka honor dan gaji para kyai, ustad/guru pun sangatlah minim. Satu nasehat Pimpinan Pondok yaitu jangan mencari makan/hidup dari pesantern tapi hidupkanlah pondok pesantren. Bila hendak mencari rezeki silakan bekerja atau mengajar ketempat lain untuk memenuhi kebutuhan hidup istri dan anaknya. Dengan konsep demikian para santri merasa wajib menghormati kyai dan ustadnya serta saling menghargai sesamanya, karena itu merupakan perintah agama. Santri yakin bahwa dirinya tidak akan menjadi orang berilmu tanpa guru dan bantuan sesamanya.

c. Kearifan; Pondok pesantren menekankan pada santri bahwa pentingnya kearifan dalam bertingkah laku sehari-hari. ${ }^{26}$ Kearifan yang dimaksud adalah bersikap berlaku sabar, rendah hati, patuh pada ketentuan hukum agama, mampu mencapai tujuan tanpa merugikan orang lain, serta dan mendatangkan manfaat bagi kepentingan bersama. Para santri Pondok pesantren Al-Quraniyah diberikan kebebasan untuk membentuk jati dirinya sebagai santri yang tunduk dan taat pada aturan pondok pesantren.

d. Kesederhanaan; Pondok pesantren menekankan pentingnya penampilan sederhana sebagai salah satu nilai luhur pondok pesantren dan menjadi pedoman perilaku sehari-hari bagi seluruh santri. ${ }^{27}$ Kesederhanaan yang dimaksudkan adalah tidak tinggi hati dan sombong pada santri lain walaupunn dia berasal dari golongan orang kaya. ${ }^{28}$ Satu hal yang unik dari pengasuh Pondok Pondok pesantren ini jika mau membeli mobil atau prabot rumah tangga, maka para pengasuh pondok berdiskusi/memberitahu santri. Ini dilakukan untuk menjelaskan bahwa apa yang mereka beli memang kebutuhan yang mendesak. Misalnya membeli mobil, dijelaskan penting untuk kepentingan tranportasi ke Bengkulu untuk mengurus administrasi Pondok Pondok pesantren AlQuraniyah. Dengan penjelasan tersebut akhirnya para santri memahami dan menerimanya. Bila dilihat kasus membeli mobil tersebut, wajar pengasuh pondok tak perlu mendiskusikan dengan santri karena tidak ada

25 Hamid Fahmy Zarkasyi, "Modern Pondok Pesantren: Maintaining Tradition in Modern System," TSAQAFAH, 2015, https://doi.org/10.21111/tsaqafah.v11i2.267.

26 Zarkasyi.

27 B. Marjani Alwi, "PONDOK PESANTREN: CIRI KHAS, PERKEMBANGAN, DAN SISTEM PENDIDIKANNYA," Lentera Pendidikan: Jurnal Ilmu Tarbiyah Dan Keguruan, 2016, https://doi.org/10.24252/lp.2013v16n2a8.

${ }^{28}$ Deviana Ika Maharani, M. Huda, A. Y, and Imron Arifin, "Manajemen Pembelajaran

Pondok Pesantren," Jurnal Manajemen Dan Supervisi Pendidikan, 2016, https://doi.org/10.17977/um025v1i12016p017. 
biaya yang dipungut dari santri, baik: uang masuk, uang makan, penginapan, uang bulanan, dan biaya lainnya.

e. Kolektivitas; Pondok pesantren Al-Quraniyah menekankan kebersamaan lebih tingi dari pribadi. Dalam keseharian pada Pondok Pondok pesantren Al-Quraniyah diutamakan kepentingan orang banyak dari pada pribadi. Dalam kewajiban santri mendahulukan diri sendiri sebelum orang lain. Untuk memutuskan sesuatu santri memelihara hal-hal baik dan mengembangkan hal-hal yang baru dan baik. Nilai ini tetap berlaku dalam kehidupan para santri yang tinggal pada kamar berukuran 5 × $8 \mathrm{~m}$ dan ditempati oleh 20 santri. Kamar tersebut sangatlah sederhana yang dibangun oleh para santri dengan cara saling membantu (gotong royong). Kemudian bila santri telah tamat (lulus) secara ikhlas kamar tersebut diberikan kepada generasi berikutnya. Para santri juga saling menolong jika terlambat uang kiriman dari uang tuanya. Mereka berusaha bersama untuk membantu meringankan masalah rekannya

f. Mengatur Kegiatan Bersama; Kegiatan bersama yang dilakukan oleh para santri biasanya bersifat relatif dan mengikat, yang dilakukan oleh santri dengan bimbingan ustad. Para santri mengatur hampir semua kegiatan proses belajar terutama berkenaan dengan kegiatan kokurikurer. Pembentukan, penyusuan sampai pelaksanaan dan pengembangannya dilakukan para santri secara bersama. Demikian juga mengatur kegiatan peribadatan, olah raga, kursus keterampilan dan sebagainya direncanakan oleh para santri dengan tidak menyimpang dari ajaran Islam dan ketentuan pondok pesantren.

g. Ukhuwah Diniyah; Kehidupan santri di pondok pesantren Al-Quraniyah penuh suasana persaudaraan yang akrab, persatuan dan gotong royong, sehingga kesenangan dirasakan bersama dan kesulitan diatasi bersama. Hal ini dapat terwujud melalui keyakinan dan pandangan hidup yang sama, bahwa manusia diciptakan dan berada di bumi ini tidak lain hanyalah untuk mengabdi kepada sang kholik, yaitu Allah SWT. Sebagai hamba yang beriman (mukmin) mereka bersaudara dengan sesama dan berbuat baik terhadap mereka. Hal ini aplikasi dari surat Al Hujurat ayat 10 yang artinya: "Sesungguhnya orang-orang mukmin itu bersaudara, karena itu damaikanlah diantara kedua saudaramu dan bertakwalah kepada Allah supaya kamu mendapat rahmat" 
h. Kebebasan; Kebebasan yang dilaksanakan oleh pondok pesantren dari segi kurikulum dan politis. ${ }^{29}$ Kebebasan kurikulum berarti Pondok pesantren Al-Quraniyah tidak terikat oleh kurikulum Kemenag dan Kemdiknas. Pondok pesantren Al-Quraniyah memliki kurikulum tambahan yaitu kurikulum pondok itu sendiri. Secara politis pondok pesantren merupakan lembaga independen, tidak berafiliasi bahkan terlibat pada salah satu partai politik atau ormas tertentu. Dalam konteks santri, kebebasan di sini berarti penanaman sikap demokratis. Mereka bebas berpikir dan bebas dalam menentukan jalan hidupnya kelak di masyarakat, optimis dalam menghadapi hidup ini. Namun semua itu dilakukan dalam batas-batas syari'at Islam.

Sistem pendidikan di pondok pesantren al-Quraniyah Manna mampu menanamkan karakter pada santri. Diantara nilai tersebut, yaitu theocentric. Menurut peneliti, penanaman nilai theocentric tentunya tidak serta merta diperoleh oleh santri. Seorang santri bisa memiliki nilai tersebut jika ia sudah menyatu dengan kegiatan yang ada di pondok pesantren sehingga lingkungan dan segala bentuk kegiatan yang ada di pondok pesantren perlahan-lahan membentuk santri agar beribadah semata-mata karena Allah SWT.

Nilai theocentric ini merupakan nilai dasar yang harus dimiliki oleh santri sebagai bekal untuk hidup di tengah-tengah masyarakat. ${ }^{30}$ Santri yang tinggal di pondok pesantren juga memiliki nilai suka rela dalam mengabdi. Nilai ini mereka dapatkan melalui kegiatan pengabdian masyarakat yang dibuat oleh Pondok pesantren. Santri yang sudah memasuki kelas tiga Aliyah diwajibkan untuk melakukan pengabdian masyarakat selama 2 minggu. Seorang santri yang memiliki nilai suka rela dalam mengabdi akan membuat dia mudah bergaul dan bersosialisasi di masyarakat maupun dunia kerja. Kearifan dan kesederhanaan merupakan nilai yang ada di pondok pesantren yang wajib dimiliki oleh santri. Seorang santri yang memiliki latar belakang yang berbeda-beda, baik ia berasal dari keluarga kaya atau mampu namun ketika ia sudah masuk ke Pondok pesantren, ia harus membiasakan hidup sederhana dan arif dalam bersikap. Sederhana bukan berarti miskin. Pondok pesantren tidak pernah mengajarkan santri untuk hidup miskin namun mengajarkan santri untuk memiliki poal hidup yang sederhana. Seorang santri nantinya ketika hidup di masyarakat boleh saja menjadi orang kaya namun pola hidup harus tetap sederhana.

29 Kelik Stiawan and Dan M Tohirin, "FORMAT PENDIDIKAN PONDOK PESANTREN SALAFI DALAM ARUS PERUBAHAN SOSIAL Di KOTA MAGELANG," CAKRAWALA, 2015.

$30 \mathrm{H}$ Engking Soewarman Hasan, "Landasan Filosofis Pengembangan Pendidikan Terpadu Pesantren (Refleksi Hasil Studi Pendidikan Terpadu Pe- Santren Di Jawa Barat)," Mimbar Pendidikan, 2001. 
Selain itu juga, santri diajarkan untuk membangun kolektivitas, membangun kebersamaan antar sesama santri. Kebersamaan atau sikap tolongmenolong yang dimiliki oleh santri tidak hanya berlaku ketika di asrama saja namun harus sudah mendarah daging sehingga bermanfaat sepanjang hayatnya. Meskipun santri sangat patuh dengan aturan yang ada di pondok pesantren, namun seorang snatri harus memiliki sikap kebebasan. Sikap kebebasan ini artinya, para santri memiliki cara berpikir yang luas, bebas berkreasi dan respon terhadap perkembangan yang terjadi di tengah-tengah masyrakat. Sikap mental seperti inilah yang membentuk santri nantinya menjadi pemimpin di negara ini. Misalnya, Hidayat Nurwahid, alumni Pondok pesantren Gontor, saat ini dipercaya sebagai Wakil Ketua MPR R.I.

Pendapat yang penulis kemukakan ini sesuai atau mendukung teori atau penelitian terdahulu yang menyatakan bahwa jenjang pondok pesantren semakin terbuka kemungkinan untuk menawarkan nilai-nilai hidup agar menjadi manusia yang berkarakter melalui berbagai kegiatan yang tidak hanya pada unsur akademis semata melainkan melalui kegiatan religius. ${ }^{31}$

\section{Peran Kiayi Dalam Membentuk Karakter Bangsa Santri}

1. Melalui Metode keteladanan.

Menurut pak Dedi Irama, ia menjelaskan bahawa, "Keteladanan dalam pendidikan di Pondok Pesantren Al-Quraniayh Bengkulu Selatan merupakan metode yang berpengaruh dalam aspek moral spiritual anak adalam remaja mengingat pendidik adalah figur terbaik dalam pandangan anak. Metode ini menurut dirinya dapat diterapkan pada usia remaja misalnya contohkan shalat, mengaji dan ibadah-ibadah atau perbuatan baik lainnya. Berdasarkan hasil observasi di Pondok Pesantren Al-Quraniyah, para guru memberikan keteladanan kepada santri dengan datang tepat waktu ke sekolah, masuk tepat waktu ke kelas, berpakaian rapi dan tidak merokok di lingkungan Pondok Pesantren. ${ }^{32}$

2. Melalui Metode Nasihat.

Metode nasihat menurut ibu Emi merupakan metode pembelajaran agama pada remaja yang cukup berhasil dalam membentuk aqidah anak (remaja) di Ponpes Al-Quraniyah Bengkulu Selatan. Metode ini menurutnya dapat mempersiapkan seorang siswa menjadi matang baik secara moral, maupun emosional. Karena menurut ibu Emi pemberia nasihat pada para santri Pondok Pesantren Al-Quraniyah Bengkulu Selatan memiliki pengaruh

\footnotetext{
${ }^{31}$ Syafe'i, "Pondok Pesantren: Lembaga Pendidikan Pembentukan Karakter."

32 Observasi di Pondok Pesantren Al-Quraniyah Manna Bengkulu Selatan
} 
yang cukup besar dalam membuka mata anak (remaja) akan hakikat sesuatu, mendorong untuk menghiasi dirinya dengan akhlak yang mulia.

Menurut Abudinnata bahwa metode nasihat cocok untuk remaja karena dengan kalimat-kalimat yang baik dapat menentukan hati untuk mengarahkannya kepada ide yang dikehendaki. Selanjutnya beliau mengatakan bahwa metode nasehat itu sasarannya adalah untuk menimbulkan kesadaran pada orang yang dinasehati agar mau insaf melaksanakan ajaran yang digariskan atau diperintahkan kepadanya. ${ }^{33}$ Berdasarkan hasil pengamatan di Pondok Pesantren Al-Quraniyah tampak bahwa ustadz/ustadza menasihati para santri yang suka membolos, terlambat datang ke sekolah dan merokok di lingkungan sekolah. ${ }^{34}$

3. Melalui Pembinaan Disiplin Siswa

Disiplin sumber kesusksesan merupakan salah satu slogan yang harus digalakkan dalam dunia pendidikan, khususnya di Pondok Pesantren AlQuraniyah Bengkulu Selatan. Disiplin siswa erat kaitannya dengan aturanaturan Pondok Pesantren yang mengikat dan harus diaati oleh siswa. Adapun contoh pembinaan kedisiplinan sntri, diantaranya ialah tidak boleh datang terlamabat masuk kelas dan bolos, pakaian, rambut harus rapi, hormat dan patuh pada guru, dilarang merokok, dan lain-lain. Patuh dan taat pada aturan sekolah menjadi konsekuensi bagi santri Pondok Pesantren Al-Quraniyah Bengkulu Selatan.

4. Melalui Kegiatan Ektra Kurikuler

Ekstrakurikuler ialah kegiatan sekolah yang pelaksanaanya diluar jam sekolah yang sudah terjadwal secara resmi. Manfaat pelaksanaan kegiatan ekstrakurikuler ini untuk siswa ialah untuk mempertajan kemampuan dalam bidang yang ia gemari. ${ }^{35}$ Melalui kegiatan ini siswa akan memperoleh nilai kebersamaan, gotong royong, sportifitas, dan kebersamaan dalam tim. ${ }^{36}$ Adapun aspek penting dalam pelaksanaan kegiatan ekstra kurikuler ialah:

a. Sebagai wadah untuk mengembangkan kreasi dan bakat santri

b. Berfungsi untuk meningkatkan keterampilan yang dimiliki santri

c. Pelaksanaan kegiatan ekstrakuirkuler tidak menggangu prestasi dan nilai akdemik santri.

33 Abuddin Nata, "Prespektif Islam Tentang Strategi Pembelajaran," Jurnal Pendidikan, 2011.

${ }^{34}$ Observasi di SMA Muhamamdiyah Bengkulu Selatan

35 Rully Khairul Anwar, Neneng Komariah, and M. Taufiq Rahman, "Pengembangan Konsep Literasi Informasi Santri: Kajian Di Pesantren Arafah Cililin Bandung Barat," Wawasan: Jurnal Ilmiah Agama Dan Sosial Budaya, 2017, https://doi.org/10.15575/jw.v2i1.964.

36 Eka Yanuarti, "Studi Komparatif Prestasi Siswa (Mengikuti Dan Tidak Mengikuti Ekstrakurikuler Rohis)," AL-ISHLAH: Jurnal Pendidikan Islam 14, no. 2 (2016). 
d. Kegiatan ekstrakurikuler bersifat fleksibel terutama mengenai waktu dan tempat pelaksanaannya.

e. Santri memiliki kebebasan memilih kegiatan ekstrakurikuler yang ia kehendaki seperti olahraga, keagamaan, music, dan lain-lain. ${ }^{37}$

\section{Faktor penghambat dan pendukung Pembentukan karakter Bangsa Santri Pondok Pesantren al-Quraniyah Manna}

1. Faktor penghambat

Berdasarkan keterangan Zahid bahwa terdapat beberapa kendala yang dihadapi Pondok pesantren al-Qur'aniyah dalam pelaksanaan pembinaan karakter mandiri dan disiplin santri, diantranya kendala yang bersifat internal (berasal dari dalam lingkungan Pondok pesantren) dan eksternal (berasal dari luar lingkungan Pondok pesantren). Kendala internal diantaranya ialah: a) belum optimalnyanya pembinaan sumber daya pengajar serta pengurus Pondok pesantren. b) Minimnya sarana dan prasarana. c) Jumlah proporsi yang tidak seimbang antara pengajar dengan jumlah santri. d) latar belakang keluarga santri. ${ }^{38}$

a. Belum optimalnya pembinaan sumber daya manusia (SDM)

Meki menjelaskan bahwa pembinaan SDM di pondok pesantren al-Quraniyah Manna belum maksimal. Pembinaan yang sudah dilakukan sebatas pengajian rutin setiap awal bulan saja untuk pengasuh pondok pesantren. Hidman menambahkan bahwa saat ini belum adanya pelatihan khusus yang dilakukan oleh pengelolah pondok pesantren untuk meningkatkan kualitas pengasuh pondok pesantren dan tenaga administrasi. ${ }^{39}$

b. Minimnya sarana dan prasarana

Pengelolaan sarana dan prasarana dalam satuan pendidikan harus dilaksanakan. Pengelolaan sarana sudah sewajarnya dilakukan oleh satuan pendidikan sekolah tidak terkecuali lembaga Pondok pesantren. Mulai dari pengadaan, pemeliharaan dan perbaikan hingga pengembangannya. ${ }^{40}$

Dari hasil wawancara dengan Aulia yang merupakan salah seorang santriwati ${ }^{41}$, dapat diketahui bahwa terdapat beberapa kendala yang salah satunya ialah masih minimnya sarana dan prasarana di lingkungan Pondok

${ }^{37}$ Wawancara dengan Pembina Ekstrakurikuler Pondok Pesantren Al-Quraniyah Manna Pada tanggal 15 Januari 2020

38 Wawancara dengan Pengasuh Pondok Pesantren Tanggal 10 Desember 2019

${ }^{39}$ Wawancara dengan Meki Pimpinan Pondok Pesantren, Wawancara 10 Desember 2019

${ }^{40}$ Janan Asifudin, "Manajemen Pendidikan Untuk Pondok Pesantren."

41 Wawancara dengan Santri Pondok Pesantren Al-Quraniyah Tanggal 12 Desember 
pesantren Al-Quraniyah, seperti jumlah santri dalam satu kamar terlalu berlebih dari jumlah idealyang seharusnya 5 santri perkamar sementara di pondok pesantren al-Quraniyah santri perkamar mencapai 10 orang, sehingga tidak mampu memberikan suasana kondusif bagi para santrinya, perlengkapan pembelajaran yang masih sederhana, sarana MCK belum memadai apabila dibandingkan dengan jumlah santri yang ada.

c. Proporsi yang tidak seimbang antara pengelola dengan jumlah santri.

Kahar mengatakan bahwa raiso antara jumlah pengajar dengan santri di pondok pesantren al-Quraniyah belum proporsional. Di lingkungan Pondok pesantren Al-Quraniyah proporsi jumlah pengajar dengan santri ialah 95 santri dengan 15 pengajar (mudaris), maka rasio antara murid dengan guru ialah 6 santri berbanding 1 pengajar. Idealnya ialah 2 orang santri diiajar oleh 1 orang ustad/ustadza. Dari angka tersebut, dapat terlihat perbandingan yang masih ideal dalam pembelajaran, akan tetapi untuk pengelolaan sebuah lingkungan pondok pesantren yang tidak hanya dilaksanakan proses pembelajaran di waktu siang hari, tetapi selama 24 jam, yang disertai dengan kegiatan lain seperti pembiasaan, ekstrakulikuler, pengajian-pengajian dan kegiatan tambahan lainnya, jumlah pengajar dirasa sangat tidak seimbang. Oleh karenanya diperlukan solusi yang lebih baik dalam menyelesaikan permasalahan tersebut.

Adapun kendala secara eksternal diantaranya ialah a) Pengaruh buruk dari perkembangan IPTEK (warnet, hp, playstation), b) Lingkungan pondok pesantren yang dilalui oleh penduduk setempat, terkadang membawa dampak negatif terhadap ahlak santri/santriah, c) Belum optimalnya hubungan Pondok pesantren dengan masyarakat.

a. Pengaruh buruk dari perkembangan IPTEK

Seharusnya perkembangan IPTEK menjadi sebuah kabar menggembirakan bagi seluruh lapisan masyarakat, tidak terkecuali pada satuan pendidikan Pondok pesantren. Akan tetapi, dari setiap perubahan, selalu ada dampak negatif yang mengiringinya. Begitupula dengan kemajuan IPTEK saat ini, adanya warnet, hp serta playstation di lingkungan Pondok pesantren al-Quraniyah (Internet dengan segala fitur yang ditawarkan) membuat para santri merasa nyaman untuk berlama-lama, hingga membolos mengikuti pengajian. Begitu pula dengan handphone yang memberi dampak kurang baik bagi para santri, para santri menghabiskan waktu untuk mengirim pesan singkat, facebookan, internetan, berfoto-foto ria dengan rekannya. Oleh karena itu, pada 
lingkungan pondok semua santri dilarang membawa alat komunikasi $(\mathrm{Hp}) .^{42}$

b. Lokasi pondok pesantren yang dilalui oleh penduduk setempat

Herawati menjelaskan, salah satu hal yang menjadi penghambat pembinaan akhlak santri ini ialah, lokasi pondok yang berada di tengahtengah lingkungan masyarkat, dan menjadi jalan keluar masuk masyarkat. Idealnya lingkungan Pondok pesantren memiliki lokasi yang tidak dilalui jalan masyarakat (terpisah dengan masyarakat), dalam rangka pembinaan yang menyeluruh dari pengelola pondok pesantren. ${ }^{43}$

c. Belum optimalnya hubungan Pondok pesantren dengan masyarakat

Hakikat hubungan sebuah lembaga pendidikan (dalam hal ini pondok pesantren) dengan masyarakat adalah untuk meningkatkan keterlibatan, kepedulian, kepemilikan serta dukungan dari masyarakat terutama dukungan moral dan finansial. Dalam rangka pembinaan akhlakul karimah para santri, terutama untuk mengembangkan potensipotensi yang dimiliki oleh pondok pesantren dan daerah, serta potensi peserta didik secara optimal.

Melalui hubungan yang optimal antara masyarakat dengan pondok pesantren diharapkan dapat membantu pondok pesantren dalam membentuk karkater/akhlak peserta didik, terutama dalam penciptaan lingkungan yang kondusif bagi perkembangan karakter pesera didik.

2. Faktor pendukung

Ada terdapat faktor internal dan faktor eksternal yang menjadi faktor pendukung implementasi pendidikan karakter pada santri pondok pesantren al-Quraniyah. ${ }^{44}$ Adapun Faktor Pendukung Internalnya ialah sebagai berikut:

a. Pondok pesantren mempunyai SDM tenaga pengajar yang memadai

Para pengasuh serta ustad dan ustadza di Pondok pesantren alQuraniyah Manna, rata-rata berlatar belakang pondok pesantren juga sehingga memudahkan dalam proses transfer ilmu maupun penanaman pendidikan karakter pada santri. Selain itu juga, ada pengasuh yang berasal dari Universitas Islam Yaman, ada juga ustad/ustadza yang sudah menyelesaikan program magister pendidikan agama Islam.

b. Santri yang mondok cukup banyak

42 Wawancara dengan Tseti Pengasuh Pondok Pesantren Pada Tanggal Tanggal 22 Desember 2019

${ }^{43}$ Wawancara dengan Emy Herawati Pengasuh Pondok Pesantren Pada Tanggal Tanggal 23 Desember 2019

44 Wawancara dengan Yurdas Pengasuh Pondok Pesantren Pada Tanggal 22 Desember 2019 
Hal ini memudahkan pihak Pondok pesantren dalam menanamkan pendidikan karakter pada anak yang mondok karena bisa berinteraksi selama 24 jam.

c. Pondok pesantren memiliki lembaga pendidikan yang lengkap tiap jenjangnya mulaidari PAUD sampai dengan Perguruan Tinggi.

Adapun faktor pendukung eksternalnya ialah sebagai berikut:

a. Pondok pesantren al-Quraniyah Manna memiliki umur yang sudah tua, sehingga masyarakat banyak yang sudah mengenal, ditambah lagi dengan sudah banyak mengeluarkan lulusan yang hebat.

b. Adanya program-program sekolah yang mendukung pengimplementasian pendidikan karakter di Pondok pesantren al-Quraniyah Manna.

c. Adanya sinergitas antara pihak Pondok pesantren dengan wali santri. Hal ini diwujudkan melalui pengajian rutin tiapa malam kamis, serta pertemuan bulanan dengan wali santri tiapbulannya.

\section{Penutup}

Beradasarkan penelitian yang telah dilakukan di Pondok pesantren alQuraniyah Manna Kabupaten Bengkulu Selatan, dapat disimpulkan bahwa peran Pondok Pesantren Al-Quraniyah dalam membentuk kaarkter santri dapat dilihat melalui impelementasi pendidikan karakter pada santri pondok pesantren alQuraniyah Manna dilakukan melalui materi yang diajarkan di pondok pesantren, program/kegiatan pondok pesantren, misal kegiatan mulok dan ekstrakurikuler, keteladanan para kyai, pengasuh asrama, ustad/ustadza yang berinteraksi dengan mereka, khususnya yang ada di lingkungan pondok pesantren. Kiayi memiliki peranan yang besar dalam membentuk karakter para santri dengan meberikan keteladanan, nasihat, dan penegakan disiplin. Faktor penghambat impelementasi pendidikan karakter pada santri pondok pesantren al-Quraniyah terbagi atas dua, yaitu faktor internal ialah: a) belum optimalnyanya pembinaan sumber daya pengajar serta pengurus Pondok pesantren. b) Minimnya sarana dan prasarana. c) Jumlah proporsi yang tidak seimbang antara pengajar dengan jumlah santri. d) latar belakang keluarga santri. Adapun faktor eksternal ialah a) Pengaruh buruk dari perkembangan IPTEK (warnet, hp, playstation), b) Lingkungan pondok pesantren yang dilalui oleh penduduk setempat, terkadang membawa dampak negatif terhadap ahlak santri/santriah, c) Belum optimalnya hubungan Pondok pesantren dengan masyarakat. Adapun Faktor pendukung impelentasi pendidikan karakter pada santri juga terdiri atas dua, yaitu faktor internalnya terdiri dari, a) Pondok pesantren mempunyai SDM tenaga pengajar yang memadai, b) Santri yang mondok cukup banyak, c) Pondok pesantren memiliki lembaga pendidikan yang lengkap tiap jenjangnya mulaidari PAUD sampai dengan Perguruan Tinggi. Adapun faktor pendukung eksternalnya ialah, a) Pondok pesantren al-Quraniyah Manna memiliki umur yang sudah tua, b) 
Adanya program-program sekolah yang mendukung pengimplementasian pendidikan karakter di Pondok pesantren al-Quraniyah Manna, c) Adanya sinergitas antara pihak Pondok pesantren dengan wali santri

\section{Bibliografy}

Alwi, B. Marjani. "Pondok pesantren: ciri khas, perkembangan, dan sistem pendidikannya." Lentera Pendidikan: Jurnal Ilmu Tarbiyah Dan Keguruan, 2016. https://doi.org/10.24252/lp.2013v16n2a8.

Anwar, Rully Khairul, Neneng Komariah, and M. Taufiq Rahman. "Pengembangan Konsep Literasi Informasi Santri: Kajian Di Pesantren Arafah Cililin Bandung Barat." Wawasan: Jurnal Ilmiah Agama Dan Sosial Budaya, 2017. https://doi.org/10.15575/jw.v2i1.964.

Depiyanti, Oci Melisa. "Model Pendidikan Karakter Di Islamic Full Day School (Studi Deskriptif Pada SD Cendekia Leadership School, Bandung)." TARBAWY: Indonesian Journal of Islamic Education, 2014. https://doi.org/10.17509/t.v1i2.3769.

Fahham, A Muchaddam. "Character Education in Islamic Boarding School." Aspirasi, 2013.

Hasan, H Engking Soewarman. "Landasan Filosofis Pengembangan Pendidikan Terpadu Pesantren (Refleksi Hasil Studi Pendidikan Terpadu Pe- Santren Di Jawa Barat)." Mimbar Pendidikan, 2001.

Herman. "Sejarah Pesantren Di Indonesia.” Jurnal Al-Ta'dib, 2013.

Jalil, Abdul. "Karakter Pendidikan Untuk Membentuk Pendidikan Karakter." Nadwa, 2016. https://doi.org/10.21580/nw.2012.6.2.586.

Janan Asifudin, Ahmad. "Manajemen Pendidikan Untuk Pondok Pesantren." MANAGERLA: Jurnal Manajemen Pendidikan Islam, 2017. https://doi.org/10.14421/manageria.2016.12-10.

Lickona, Thomas. "Educating for Character: A Comprehensive Approach." In The Construction of Children's Character., 1997.

Maharani, Deviana Ika, M. Huda, A. Y, and Imron Arifin. "Manajemen Pembelajaran Pondok Pesantren." Jurnal Manajemen Dan Supervisi Pendidikan, 2016. https://doi.org/10.17977/um025v1i12016p017.

Maksum, Ali. "Model Pendidikan Toleransi Di Pesantren Modern Dan Salaf." Jurnal Pendidikan Agama Islam (Journal of Islamic Education Studies), 2016. https://doi.org/10.15642/pai.2015.3.1.81-108.

Maunah, Binti. "Implementasi Pendidikan Karakter Dalam Pembentukan 
Kepribadian Holistik Siswa." Jurnal Pendidikan Karakter, 2016. https://doi.org/10.21831/jpk.v0i1.8615.

Nata, Abuddin. "Prespektif Islam Tentang Strategi Pembelajaran." Jurnal Pendidikan, 2011.

Niam, Zainun Wafiqatun. "Membina Karakter Anak Melalui Program Full Day School Berbasis Nilai-Nilai Kepesantrenan (Studi Kasus Di Madrasah Ibtidaiyah Nurul Ummah Kotagede Yogyakarta)." BELAJEA: Jurnal Pendidikan Islam, 2019. https://doi.org/10.29240/belajea.v4i1.696.

NUR, HAERANI. "Building Children's Character through Traditional Games." Junal Pendidikan Karakter, 2013.

"Potret pendidikan karakter di pondok pesantren salafiah." Jurnal Pendidikan Karakter, 2013. https://doi.org/10.21831/jpk.v0i3.1246.

Ruyadi, Yadi. "Model Pendidikan Karakter Berbasis Kearifan Budaya Lokal (Penelitian Terhadap Masyarakat Adat Kampung Benda Kerep Cirebon Provinsi Jawa Barat Untuk Pengembangan Pendidikan Karakter Di Sekolah)." Proceedings of The 4th International Conference on Teacher Education; Join Conference UPI \& UPSI, 2010.

Srimulyani, Eka. “ Muslim Women and Education in Indonesia: The Pondok Pesantren Experience ." Asia Pacific Journal of Education, 2007. https://doi.org/10.1080/02188790601145564.

Stiawan, Kelik, and Dan M Tohirin. "format pendidikan pondok pesantren salafi dalam arus perubahan sosial di kota magelang." cakrawala, 2015.

Supriadin, Supriadin. "Politik Pendidikan Islam Di Indonesia: Analisis Sistem Pendidikan Pesantren Dan Madrasah." EL-HIKMAH: Jurnal Kajian Dan Penelitian Pendidikan Islam, 2014. https://doi.org/10.20414/elhikmah.v8i2.250.

Syafe'i, Imam. "Pondok Pesantren: Lembaga Pendidikan Pembentukan Karakter." Al-Tadzkizyah: Jurnal Pendidikan Islam, 2017. https://doi.org/10.24042/atjpi.v8i1.2097.

Usman, Muhammad Idris. "Pesantren Sebagai Lembaga Pendidikan Islam (Sejarah Lahir, Sistem Pendidikan, Dan Perkembangannya Masa Kini)." Jurnal Al-Hikmah, 2013.

Yanuarti, Eka. "Studi Komparatif Prestasi Siswa (Mengikuti Dan Tidak Mengikuti Ekstrakurikuler Rohis)." Al-Ishlab: Jurnal Pendidikan Islam 14, no. 2 (2016).

Zarkasyi, Hamid Fahmy. "Modern Pondok Pesantren: Maintaining Tradition in 
262 | Belajea: Jurnal Pendidikan Islam, Vol. 5, No. 2, 2020

Modern

System."

Tsaqafah,

2015.

https://doi.org/10.21111/tsaqafah.v11i2.267.

Zawawi, Abdullah. "Peranan Pondok Pesantren Dalam Menyiapkan Generasi Muda Di Era Globalisasi.” Ummul Quro, 2013.

Zuhriy, M. Syaifuddien. "Budaya pesantren dan pendidikan karakter pada pondok pesantren salaf." Walisongo: Jurnal Penelitian Sosial Keagamaan, 2011. https://doi.org/10.21580/ws.2011.19.2.159. 